\title{
Original article (Orijinal araştırma) \\ Response of tomato plants carrying Mi-1 gene to Meloidogyne incognita (Kofoid \& White, 1919) Chitwood, 1949 under high soil temperatures ${ }^{1}$
}

\author{
Yüksek toprak sıcaklıklarında Mi-1 genini taşıyan domates bitkilerinin Meloidogyne \\ incognita (Kofoid \& White, 1919) Chitwood, 1949'a tepkisi \\ Tevfik ÖZALP2 \\ Zübeyir DEVRAN ${ }^{*}$
}

\begin{abstract}
The Mi-1 gene conferring resistance to root-knot nematodes in tomato breaks down at soil temperatures above $28^{\circ} \mathrm{C}$. To understand this phenomenon, the reactions of susceptible and resistant tomatoes to Meloidogyne incognita (Kofoid \& White, 1919) Chitwood, 1949 were separately investigated under four soil temperatures, $25,28,30$ and $32^{\circ} \mathrm{C}$, and at six time periods, 6, 12, 24, 48, 120 and $168 \mathrm{~h}$. The study was conducted between 2015 and 2016 in growth chambers. In the first experiment, the plants were separately exposed to soil temperatures for the same six periods before nematode inoculation and then transferred to a growth chamber with $25^{\circ} \mathrm{C}$. Reproduction factor (Rf) for nematode on resistant plants was $<1$, while the Rf for susceptible plants was $>1$. Results indicated that the resistance provided by $\mathrm{Mi}-1$ persisted under all soil temperatures. In the second experiment, the seedlings were simultaneously inoculated with $M$. incognita when soil temperatures reached $25,28,30$ and $32^{\circ} \mathrm{C}$, and held in soil temperatures for the same six periods, then transferred to a growth chamber with $25^{\circ} \mathrm{C}$ soil temperature. Rf in heterozygous resistant plants exposed to $32^{\circ} \mathrm{C}$ soil temperature for $\geq 48 \mathrm{~h}$ was $>1$. This study indicated that the resistance in plants held at $32^{\circ} \mathrm{C}$ soil temperature for $\geq 48 \mathrm{~h}$ lost its effect.
\end{abstract}

Keywords: Duration, Mi-1 gene, resistance, root-knot nematodes, soil temperature, tomato

\section{Öz}

Domateste kök ur nematodlarına karşı dayanıklılık sağlayan Mi-1 geni $28^{\circ} \mathrm{C}$ 'nin üzerindeki toprak sıcaklılarında kırımaktadır. Bu durumu anlamak için Meloidogyne incognita (Kofoid \& White, 1919) Chitwood, 1949' ya hassas ve dayanıklı bitkiler, dört toprak sıcaklığında $\left(25,28,30\right.$ ve $\left.32^{\circ} \mathrm{C}\right)$ ve 6 sürede $(6,12,24,48,120$ ve 168 saat) ayrı ayrı incelenmiştir. Bu çalışma 2015 ve 2016 yılları arasında iklim odalarında yürütülmüştür. İlk denemede bitkiler nematod inokulasyonundan önce aynı altı zaman periyodu için $25,28,30$ ve $32^{\circ} \mathrm{C}$ toprak sıcaklıklarına maruz bırakılmış, daha sonra $25^{\circ} \mathrm{C}$ 'deki iklim odasına aktarılmıştır. Nematodların üreme faktörü (Rf) dayanıkıı bitkilerde 1 'den büyük hassas bitkilerde ise 1'den küçük bulunmuştur. İlk denemenin sonucu, Mi-1 tarafından sağlanan dayanıklılı̆ın belirtilen toprak sıcaklıklarında kııımadığını göstermişsir. İkinci denemede toprak sıcaklıkları $25^{\circ} \mathrm{C}, 28^{\circ} \mathrm{C}, 30^{\circ} \mathrm{C}$ ve $32^{\circ} \mathrm{C}$ ye ulaştığında eş zamanlı olarak $M$. incognita inokulasyonu yapılmış ve adı geçen sürelerde toprak sıcaklığına maruz bırakılmıştır. Daha sonra bitkiler $25^{\circ} \mathrm{C}$ toprak sıcaklığına sahip iklim odasına aktarılmıştır. $32^{\circ} \mathrm{C}$ toprak sıcaklığına, 48 saat ve üzerinde maruz bırakılan heterozigot dayanıklı bitkilerde Rf değeri $>1$ olarak bulunmuştur. Bu sonuçlar $32^{\circ} \mathrm{C}$ toprak sıcaklığına, 48 saat ve üzeri maruz bırakılan bitkilerdeki dayanıklıı̆ı̆ etkisini yitirdiğini göstermiştir.

Anahtar sözcükler: Süre, Mi-1 geni, dayanıklılık, kök-ur nematodları, toprak sıcaklığı, domates

\footnotetext{
${ }^{1}$ This study represents first author's master thesis.

${ }^{2}$ Akdeniz University, Agricultural Faculty, Plant Protection Department, 07058, Antalya, Turkey

* Corresponding author (Sorumlu yazar) e-mail: zdevran@akdeniz.edu.tr

Received (Alınış): 04.10.2018 Accepted (Kabul ediliş): 06.12.2018 Published Online (Çevrimiçi Yayın Tarihi): 24.12.2018
} 


\section{Introduction}

Tomato is a widely grown vegetable with an annual worldwide yield of about 173 million ton/year (FAO, 2014). It is also a major dietary source of lycopene, which reduces the risk of developing heart disease and cancer (Clinton et al., 1996; Arab \& Steck, 2000). As with other crop plants, many pests and pathogens attack cultivated tomatoes, damaging both quality and quantity of production. Root-knot nematodes (RKN), Meloidogyne spp., are considered a major pest in tomato-growing areas. They feed and develop on plant roots, resulting in the formation of galls or knots, which cause reduced water and nutrients uptake (Duncan \& Noling, 1998). As a result, plants may exhibit unspecific symptoms, which can be confused with water and nutrient deficiency (Duncan \& Noling, 1998). In addition, plants can become more susceptible to fungal and bacterial diseases (Taylor \& Sasser, 1978; Siddiqui et al., 2014; Al-Hazmi \& AlNadary, 2015; Lobna et al., 2016).

Management of RKN is difficult due to their polyphagous nature (Siddiqi, 2000), reproduction capacity (Moens et al., 2009), being soilborne pathogens (Starr et al., 1989; Manzanilla-López \& Starr, 2009) having a wide range of host (Hussey, 1985). Pesticides, resistant cultivars and rootstocks are commonly used to manage RKN (Devran et al., 2010). Nematicides have been widely used to RKN control. However, the use of some nematicides has been restricted owing to human health and environmental concerns (Devran et al., 2008; Moens et al., 2009; Devran et al., 2013). Therefore, growing resistant cultivars is considered an alternative and environmentally-friendly strategy to manage RKN (Devran et al., 2013). In tomatoes, Mi-1 controls resistance to RKN. This gene was introgressed into cultivated tomato from wild tomato Solanum peruvianum L. (Solanaceae) in the 1940s (Smith, 1944). It confers resistance against three species of RKN: Meloidogyne incognita (Kofoid \& White, 1919) Chitwood, 1949, Meloidogyne javanica (Treub, 1885) and Meloidogyne arenaria (Neal, 1889) Chitwood, 1949 (Roberts \& Thomason, 1986). Mi-1 gene-mediated resistance is characterized by a localized hypersensitive response to the attempt of a nematode to initiate a feeding site in root cells (Dropkin, 1969a). This gene has been successfully incorporated into many commercially available tomato cultivars and is currently the only source of RKN resistance in commercial tomatoes (Devran et al., 2010; Seid et al., 2015). This gene also confers resistance to the aphid Macrosiphum euphorbiae (Thomas, 1878) (Homoptera: Aphididae) and Bemisia tabaci (Gennadius, 1889) (Hemiptera: Aleyrodidae) biotypes Q and B (Rossi et al., 1998; Nombela et al., 2003). However, the resistance conferred by Mi-1 gene has limited. The gene loses its effectiveness at soil temperatures of above $28^{\circ} \mathrm{C}$ (Dropkin, 1969b). However, there are discrepancies in information about the recovery and the duration of resistance breakdown provided by Mi-1 gene at high soil temperatures. Dropkin (1969b) reported that the phenotypic expression of resistance provided by the gene changed at temperatures above $28^{\circ} \mathrm{C}$. Araujo et al. (1982a) observed numerous egg masses on roots of plants incubated for $3 \mathrm{~d}$ at $25^{\circ} \mathrm{C}$, then moved to $32.5^{\circ} \mathrm{C}$ for $27 \mathrm{~d}$ in their reciprocal experiment. In contrast, Haroon et al. (1993) reported that there were no galls on in vitro root explant tissues of resistant tomatoes maintained at $28^{\circ} \mathrm{C}$ or $30^{\circ} \mathrm{C}$ for $10 \mathrm{~d}$; however, galls were present on roots at $33^{\circ} \mathrm{C}$ and increased at 37 and $40^{\circ} \mathrm{C}$. Similarly, when in vitro root explants without $\mathrm{Mi}-1$ gene and resistant genotypes carrying $\mathrm{Mi}-1$ gene were inoculated with $M$. incognita and $M$. arenaria at $28,31,34$ and $37^{\circ} \mathrm{C}$, heterozygous and homozygous genotypes were equally resistant to both RKN species and genotypes lacking Mi-1 gene were susceptible to all temperatures. In addition, the resistance level was maintained fully at $31^{\circ} \mathrm{C}$, maintained partially at $34^{\circ} \mathrm{C}$ and lost at $37^{\circ} \mathrm{C}$ (Abdul-Baki et al., 1996). In several studies, tomato plants with the Mi-1 gene were inoculated with $M$. incognita after heat treatment at five temperatures between 27 and $38^{\circ} \mathrm{C}$. Consequently, the seedlings showed increased susceptibility to $M$. incognita above $30^{\circ} \mathrm{C}$ with the maximum reached at $34^{\circ} \mathrm{C}$ (Zacheo et al., 1995). Carvalho et al. (2015) reported that for plants exposed to ambient temperatures of $35^{\circ} \mathrm{C}$ for $3 \mathrm{~h}$ daily (midday), resistance level could be recovered by maintaining them in a low temperature for $6 \mathrm{~d}$. Unlike under controlled conditions, when the soil temperature reached above $28^{\circ} \mathrm{C}$ under greenhouse, Mi-1-mediated resistance reduced greatly (Cortada et al., 2008). 
Although the effect of temperatures on RKN resistance under different temperatures has been extensively studied, the results remain inconclusive. Unlike many previous studies, in this study, the soil temperature was constantly monitored with a probe, and the inoculation time and heat exposure periods recorded. This study examined the reactions of (a) tomatoes bearing Mi-1 gene to M. incognita at high soil temperatures, and (b) tomatoes cultivars with or lacking the Mi-1 gene to $M$. incognita exposed to soil temperatures of $25,28,30$ and $32^{\circ} \mathrm{C}$ for $6,12,24,48,120$ and $168 \mathrm{~h}$. The purpose was to determine the time of resistance break down in heterozygous and homozygous tomato cultivars at the Mi locus exposed to high soil temperatures and then simultaneously inoculated with $M$. incognita.

\section{Material and Methods}

The study was conducted at Plant Protection Department, Faculty of Agriculture Akdeniz University, Antalya, Turkey between 2015 and 2016.

\section{Plant material}

The homozygous tomato cv. Tueza F1 without the Mi-1 gene (mimi), the heterozygous cv. Seval F1 at the Mi-1 locus (Mimi) and the homozygous cv. Browny F1 at the Mi-1 locus (MiMi) were used in the bioassay. Tomato seedlings were provided by Multi Tohum Tar. San Tic. A.Ş. (Antalya, Turkey). Individual tomato seedlings were transferred to $250-\mathrm{mL}$ pots including sterilized sandy soil.

\section{Nematode isolate}

The S6 isolate of $M$. incognita race 2 was used in the experiments. This isolate was previously described and characterized (Devran \& Söğüt, 2009, 2011). The isolate was maintained in the susceptible tomato cv. Tueza F1. Tomato plants were inoculated with 1000 J2 (Devran et al., 2010; Devran \& Söğüt, 2014; Mıstanoğlu et al., 2016) and maintained in a growth chamber at $25 \pm 0.5^{\circ} \mathrm{C}$ with $16: 8 \mathrm{~h} \mathrm{~L}: \mathrm{D}$ photoperiod and $65 \% \mathrm{RH}$. Eight weeks after nematode inoculation the tomato plants were uprooted and the roots were washed free of soil. Then, the egg masses were handpicked and incubated in a petri dish at room temperate. The juveniles ( $\mathrm{J} 2$ ) were collected at first $24 \mathrm{~h}$, counted and inoculated in new tomato plants in the same day or stored in refrigerator at $4^{\circ} \mathrm{C}$ for $2 \mathrm{~d}$, until inoculation.

\section{DNA isolation}

Plant genomic DNA and nematode DNA were isolated according to previous studies (Devran \& Söğüt, 2009; Devran et al., 2013).

\section{PCR amplification}

The S6 isolate of $M$. incognita race 2 was verified the use of Inc14F/Inc14R primers (Randig, 2002). DNA of $M$. arenaria (K18) and M. javanica (AKS2) isolates was included as controls. The K18 and AKS2 isolates were identified and characterized in previous studies (Devran \& Söğüt, 2009, 2011). The presence of Mi-1 gene in tomato plants was verified using the Mi23 marker (Seah et al., 2007). All PCR reactions were performed according to previous studies (Devran \& Söğüt, 2009, 2014; Devran et al., 2013).

\section{Effect of high temperatures on tomato resistance against $M$. incognita}

Two different experimental designs were used, a) plants heat treated before nematode inoculation, and b) plants heat treated and inoculated simultaneously. Soil temperature in pots was continuously monitored with a probe and registered.

Experiment 1: Tomato seedlings (five replicates/treatment) with four true leaves individually exposed to soil temperatures of $25,28,30$ and $32^{\circ} \mathrm{C}$ for $6,12,24,48,120$ and $168 \mathrm{~h}$ (Figure 1a). Then, the plants were transferred to a growth chamber at $25^{\circ} \mathrm{C}$ with $16: 8 \mathrm{~h} \mathrm{L:D}$ photoperiod and $65 \% \mathrm{RH}$. When the soil temperature reached $25^{\circ} \mathrm{C}$, tomato seedlings were inoculated with 1000 freshly hatched $M$. incognita J2s (Figure 1b). The experiment was set up, performed and then repeated. 


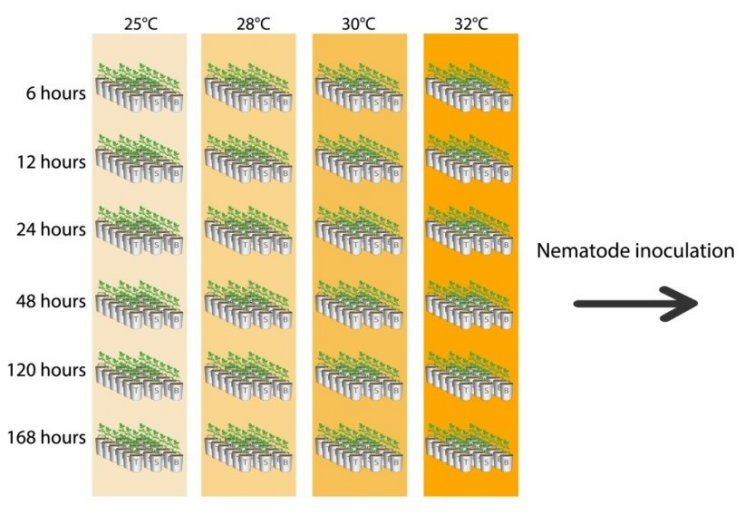

A

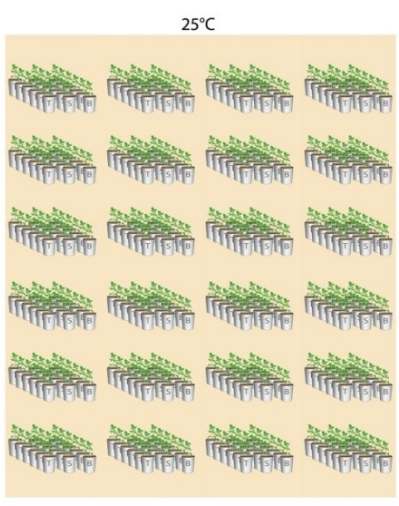

B

Figure 1. Design of the experiments to study the effect of high temperatures on tomato resistance. A) Tomato seedlings were individually exposed to four soil temperatures for different time periods, before inoculation with Meloidogyne incognita secondstage juveniles (J2); B) Tomato seedlings were exposed to different soil temperatures, inoculated with $\mathrm{J} 2$ and maintained for different time periods at $25^{\circ} \mathrm{C}$.

Experiment 2: The tomato plants (five replicates/treatment) were exposed to soil temperatures of 25,28 , 30 and $32^{\circ} \mathrm{C}$ for $6,12,24,48,120$ and $168 \mathrm{~h}$. When soil reached the designated temperature, plants were inoculated with 1000 freshly hatched $(<24$ h) M. incognita J2s (Figure 2a). The plants were held in soil temperatures for the same six periods and then transferred to a growth chamber at $25^{\circ} \mathrm{C}$, as referred before, until the end of the experiment (Figure 2b). The experiment was designed, conducted and then repeated.

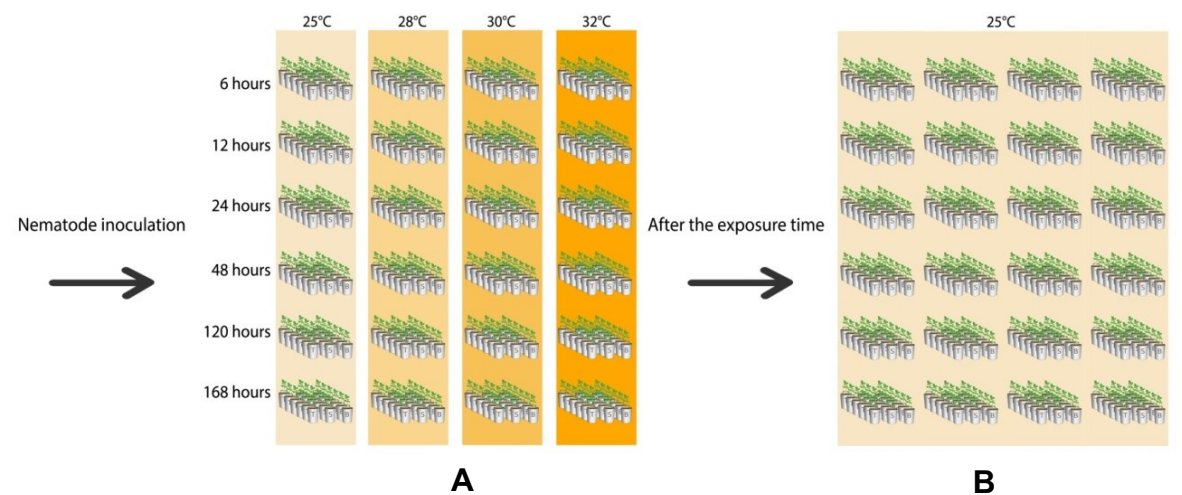

Figure 2. Design of the experiments to study the effect of high temperatures on tomato resistance A) The tomato seedlings separately exposed to four soil temperatures for different time periods and inoculated with Meloidogyne incognita second-stage juveniles; B) Plants transferred to a growth chamber with $25^{\circ} \mathrm{C}$.

Sixty day after inoculation the plants were evaluated. The number of galls and egg masses per root system was recorded in all experiments. Galls and egg masses were counted under a stereomicroscope. $\mathrm{J} 2$ were recovered from the soil of each pot (100 g soil/pot) using a modified Baermann funnel technique within 2 d (Hooper, 1986). Reproduction factor (RF; i.e., final J2 population density/initial nematode population, $1000 \mathrm{~J} 2 \mathrm{~s}$ ) was calculated (Ferris, 1985). The data (number of egg masses, galls and J2s) data were log transformed $[\log 10(x+1)]$ and analyzed by ANOVA. The significant differences within treatments were tested using LSD. The statistical analysis was performed according to SAS program (v. 9.0 for Windows; SAS Institute Inc., Cary, NC, USA). 


\section{Results and Discussion}

\section{Confirmation of nematode isolate identification and detection of Mi-1 gene}

The $M$. incognita isolate S6 identification was confirmed by PCR using species-specific primers (Inc14F/Inc14R), which produced an amplicon of about $400 \mathrm{bp}$, as expected (Figure 3a).

The Mi-1 gene was verified using the Mi23 marker. This marker allows the amplification of 430-bp and 380-bp fragments for tomato cultivars without the Mi-1 gene (mimi) and homozygous tomato cultivars at the $\mathrm{Mi}$ locus (MiMi), respectively. Heterozygous tomato cultivars (Mimi) presented the two fragments, as expected (Figure 3b).

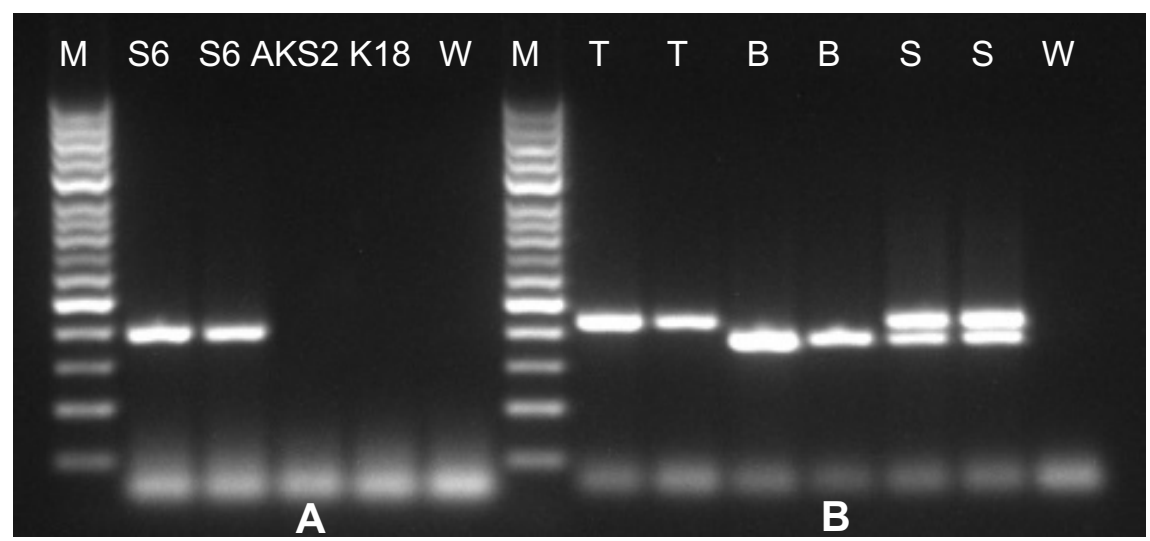

Figure 3. A) Amplified DNA of Meloidogyne incognita using primers Inc14F/Inc14R and B) PCR products of tomato cultivars using primers Mi23F/R. M: Marker (100 bp DNA Ladder, GeneAll, Seoul, Korea), S6: M. incognita, AKS2: M. javanica, K18: M. arenaria, T: Tueza F1 (mimi), B: Browny F1 (MiMi), S: Seval F1 (Mimi), W: Negative control.

\section{Effect of high temperatures on tomato resistance}

Experiment 1: At the end of the experiment, the number of $\mathrm{J} 2 \mathrm{~s}$, egg masses and galls was evaluated for all plants (Table 1). The data indicated the resistance conferred by Mi-1 persisted at the soil temperatures tested. Rf values of $M$. incognita on tomato plants (mimi) was $>1$ while on tomato cultivars (MiMi or Mimi) were $<1$, as expected (Table 1). Rf value of plants exposed to heat treatment at $32^{\circ} \mathrm{C}$ is shown in Table 1.

Experiment 2: The tomato seedlings exposed to soil temperatures for the six time periods at the time of inoculation and parameters were evaluated (Table 2). The data showed marginal increases in the number of galls and egg masses on the roots of tomato plants (MiMi) held at $30^{\circ} \mathrm{C}$ soil temperature for $>120 \mathrm{~h}$ (Table 2). However, resistance did not break down and Rf values of $M$. incognita on homozygous (MiMi) and heterozygous (Mimi) tomato plants were $<1$ (Table 2). The number of egg masses on the roots of $\mathrm{cv}$. Browny F1 (MiMi) held at $32^{\circ} \mathrm{C}$ did not change at 6 and $12 \mathrm{~h}$ but increased to statistical significance at $24 \mathrm{~h}$ and markedly increased $>48 \mathrm{~h}$. The Rf of $M$. incognita on tomato seedlings (Mimi) at $32^{\circ} \mathrm{C}$ for $\geq 48 \mathrm{~h}$ was $>1$. However, the results also demonstrated that the Rf of nematodes on tomato plants $(M i M i)$ exposed to $32^{\circ} \mathrm{C}$ soil temperature for 120 and $168 \mathrm{~h}$ were $>1$ (Table 2). So, the present study demonstrates that Mi-1 genemediated resistance in tomato breaks down in plants held at $32^{\circ} \mathrm{C}$ for $\geq 48 \mathrm{~h}$. 
Table 1. Number of galls, egg masses and Rf of Meloidogyne incognita on tomato cultivars exposed to different temperatures before inoculation with 1000 second-stage juveniles

\begin{tabular}{|c|c|c|c|c|c|c|c|c|}
\hline \multirow{2}{*}{$\begin{array}{c}\text { Soil } \\
\text { temperature }\end{array}$} & \multirow{2}{*}{ Parameters } & \multirow{2}{*}{$\begin{array}{l}\text { Tomato } \\
\text { cultivars* }\end{array}$} & \multicolumn{6}{|c|}{ Hours of exposure } \\
\hline & & & 6 & 12 & 24 & 48 & 120 & 168 \\
\hline \multirow{6}{*}{$25^{\circ} \mathrm{C}$} & & Tueza F1 & $148.4 a^{\star *}$ & $127.8 \mathrm{a}$ & $158.0 \mathrm{a}$ & $136.6 \mathrm{a}$ & $168.2 \mathrm{a}$ & $95.0 \mathrm{a}$ \\
\hline & Gall & Seval F1 & $4.8 \mathrm{~b}$ & $0.4 \mathrm{e}$ & $0.8 \mathrm{de}$ & $2.6 \mathrm{bcd}$ & 2.0 bcde & $3.4 \mathrm{bc}$ \\
\hline & & Browny F1 & $0.4 \mathrm{e}$ & $3.6 \mathrm{~b}$ & $2.0 \mathrm{cde}$ & 1.6 bcde & $1.6 \mathrm{cde}$ & $2.0 \mathrm{cde}$ \\
\hline & & Tueza F1 & $83.0 \mathrm{a}$ & $44.4 \mathrm{~b}$ & $65.2 \mathrm{a}$ & $70.4 \mathrm{a}$ & $77.8 \mathrm{a}$ & $61.8 \mathrm{a}$ \\
\hline & Egg Mass & Seval F1 & $0.6 \mathrm{c}$ & $0.0 \mathrm{~d}$ & $0.2 \mathrm{~cd}$ & $0.4 \mathrm{~cd}$ & $0.0 \mathrm{~d}$ & $0.2 \mathrm{~cd}$ \\
\hline & & Browny F1 & $0.0 \mathrm{~d}$ & $0.2 \mathrm{~cd}$ & $0.2 \mathrm{~cd}$ & $0.0 \mathrm{~d}$ & $0.0 \mathrm{~d}$ & $0.0 \mathrm{~d}$ \\
\hline \multirow{6}{*}{$28^{\circ} \mathrm{C}$} & & Tueza F1 & $122.4 \mathrm{a}$ & $127.0 \mathrm{a}$ & $87.4 \mathrm{~b}$ & $111.2 \mathrm{a}$ & $81.0 a b$ & $89.6 a b$ \\
\hline & Gall & Seval F1 & $1.2 \mathrm{de}$ & $4.8 \mathrm{c}$ & $3.4 \mathrm{~cd}$ & $0.0 \mathrm{e}$ & $1.4 \mathrm{de}$ & $2.2 \mathrm{de}$ \\
\hline & & Browny F1 & $0.2 \mathrm{e}$ & $0.4 \mathrm{e}$ & $0.0 \mathrm{e}$ & $0.6 \mathrm{e}$ & $0.0 \mathrm{e}$ & $0.0 \mathrm{e}$ \\
\hline & & Tueza F1 & $76.0 \mathrm{a}$ & $65.8 \mathrm{ab}$ & $50.0 \mathrm{c}$ & $58.6 a b$ & $40.2 \mathrm{bc}$ & $40.8 \mathrm{abc}$ \\
\hline & Egg Mass & Seval F1 & $0.2 \mathrm{de}$ & $0.6 \mathrm{de}$ & $0.4 \mathrm{de}$ & $1.6 \mathrm{~d}$ & $0.0 \mathrm{e}$ & $0.2 \mathrm{de}$ \\
\hline & & Browny F1 & $0.2 \mathrm{de}$ & $0.0 \mathrm{e}$ & $0.0 \mathrm{e}$ & $0.0 \mathrm{e}$ & $0.0 \mathrm{e}$ & $0.0 \mathrm{e}$ \\
\hline \multirow{6}{*}{$30^{\circ} \mathrm{C}$} & & Tueza F1 & $149.2 \mathrm{a}$ & $89.2 a b$ & $106.4 \mathrm{ab}$ & $86.0 \mathrm{ab}$ & $66.2 \mathrm{~b}$ & $124 \mathrm{a}$ \\
\hline & Gall & Seval F1 & $2.0 \mathrm{de}$ & $1.8 \mathrm{de}$ & $5.6 \mathrm{c}$ & $4.0 \mathrm{~cd}$ & $1.8 \mathrm{de}$ & $1.4 \mathrm{de}$ \\
\hline & & Browny F1 & $0.2 \mathrm{e}$ & $1.2 \mathrm{de}$ & $1.4 \mathrm{e}$ & $0.6 \mathrm{e}$ & $1.2 \mathrm{e}$ & $1.0 \mathrm{e}$ \\
\hline & & Tueza F1 & $46.6 \mathrm{a}$ & $58 \mathrm{a}$ & $52.4 \mathrm{a}$ & $48.8 \mathrm{a}$ & $14.6 \mathrm{~b}$ & $74.4 \mathrm{a}$ \\
\hline & Egg Mass & Seval F1 & $0.2 \mathrm{c}$ & $0.4 \mathrm{c}$ & $0.2 \mathrm{c}$ & $0.4 \mathrm{c}$ & $0.4 \mathrm{c}$ & $0.8 \mathrm{c}$ \\
\hline & & Browny F1 & $0.2 \mathrm{c}$ & $0.6 \mathrm{c}$ & $0.4 \mathrm{c}$ & $0.0 \mathrm{c}$ & $0.0 \mathrm{c}$ & $0.4 \mathrm{c}$ \\
\hline \multirow{9}{*}{$32^{\circ} \mathrm{C}$} & & Tueza F1 & $81.8 \mathrm{a}$ & $124.8 \mathrm{a}$ & $98.6 \mathrm{a}$ & $126.2 \mathrm{a}$ & $125.4 \mathrm{a}$ & $79.5 \mathrm{a}$ \\
\hline & Gall & Seval F1 & $0.6 \mathrm{de}$ & $4.6 \mathrm{~b}$ & $4.4 \mathrm{~b}$ & $3.2 \mathrm{bc}$ & $0.0 \mathrm{e}$ & $1.2 \mathrm{cde}$ \\
\hline & & Browny F1 & $1.2 \mathrm{~cd}$ & $0.4 \mathrm{de}$ & $0.6 \mathrm{de}$ & $1.2 \mathrm{~cd}$ & $0.4 \mathrm{de}$ & $0.0 \mathrm{e}$ \\
\hline & & Tueza F1 & $42.8 \mathrm{a}$ & $48.2 \mathrm{a}$ & $50.4 a$ & $54.2 \mathrm{a}$ & $57.4 \mathrm{a}$ & $54.5 \mathrm{a}$ \\
\hline & Egg Mass & Seval F1 & $0.0 \mathrm{~b}$ & $0.0 \mathrm{~b}$ & $0.0 \mathrm{~b}$ & $0.2 \mathrm{~b}$ & $0.4 \mathrm{~b}$ & $0.0 \mathrm{~b}$ \\
\hline & & Browny F1 & $0.4 \mathrm{~b}$ & $0.0 \mathrm{~b}$ & $0.0 \mathrm{~b}$ & $1.0 \mathrm{~b}$ & $0.2 \mathrm{~b}$ & $0.0 \mathrm{~b}$ \\
\hline & & Tueza F1 & $2.63 \mathrm{c}$ & $3.90 \mathrm{~b}$ & $4.12 \mathrm{~b}$ & $1.12 \mathrm{~d}$ & $5.08 \mathrm{~b}$ & $7.91 \mathrm{a}$ \\
\hline & $\mathrm{Rf}$ & Seval F1 & $0.004 \mathrm{e}$ & $0.012 \mathrm{e}$ & $0.0 \mathrm{e}$ & $0.0 \mathrm{e}$ & $0.04 \mathrm{e}$ & $0.004 \mathrm{e}$ \\
\hline & & Browny F1 & $0.0 \mathrm{e}$ & $0.004 \mathrm{e}$ & $0.008 \mathrm{e}$ & $0.008 \mathrm{e}$ & $0.0 \mathrm{e}$ & $0.0 \mathrm{e}$ \\
\hline
\end{tabular}

* Tueza $\mathrm{F}_{1}$ : without Mi gene (mimi), Seval $\mathrm{F}_{1}$ : heterozygous (Mimi), Browny $\mathrm{F}_{1}$ : homozygous carrying the Mi gene (MiMi).

** Means with in the temperature sharing the same letter are not significantly different from each other at $P=0.05$ according to the LSD.

Untransformed data shown, statistical analysis was performed on $\log (x+1)$ transformed data. 
Table 2. Number of galls, egg masses and Rf of Meloidogyne incognita on tomato cultivars exposed to different temperatures after inoculation with 1000 second-stage juveniles

\begin{tabular}{|c|c|c|c|c|c|c|c|c|}
\hline \multirow{2}{*}{$\begin{array}{c}\text { Soil } \\
\text { temperature }\end{array}$} & \multirow{2}{*}{ Parameters } & \multirow{2}{*}{$\begin{array}{l}\text { Tomato } \\
\text { cultivars* }^{*}\end{array}$} & \multicolumn{6}{|c|}{ Hours of exposure } \\
\hline & & & 6 & 12 & 24 & 48 & 120 & 168 \\
\hline \multirow{6}{*}{$25^{\circ} \mathrm{C}^{* *}$} & & Tueza F1 & - & - & - & - & - & $168.2 \mathrm{a}$ \\
\hline & Gall & Seval F1 & - & - & - & - & - & $2.0 \mathrm{~b}$ \\
\hline & & Browny F1 & - & - & - & - & - & $0.0 \mathrm{c}$ \\
\hline & & Tueza F1 & - & - & - & - & - & $84.4 \mathrm{a}$ \\
\hline & Egg Mass & Seval F1 & - & - & - & - & - & $0.0 \mathrm{~b}$ \\
\hline & & Browny F1 & - & - & - & - & - & $0.0 \mathrm{~b}$ \\
\hline \multirow{6}{*}{$28^{\circ} \mathrm{C}$} & & Tueza F1 & $81.0 a^{\star \star \star}$ & $66.2 \mathrm{a}$ & $71.0 \mathrm{a}$ & $75.5 \mathrm{a}$ & $69.5 \mathrm{a}$ & $63.2 \mathrm{a}$ \\
\hline & Gall & Seval F1 & $3.2 \mathrm{bcd}$ & 1.0 ef & $3.0 \mathrm{bcd}$ & $4.5 \mathrm{bc}$ & $2.5 \mathrm{cde}$ & $5.0 \mathrm{~b}$ \\
\hline & & Browny F1 & $0.0 \mathrm{f}$ & 1.5 cde & 0.7 ef & 1.0 ef & $2.0 \mathrm{cde}$ & $1.2 \mathrm{de}$ \\
\hline & & Tueza F1 & $54.2 \mathrm{a}$ & $47.5 \mathrm{a}$ & $62.7 \mathrm{a}$ & $57.5 \mathrm{a}$ & $51.5 \mathrm{a}$ & $45.5 \mathrm{a}$ \\
\hline & Egg Mass & Seval F1 & $0.7 \mathrm{~b}$ & $0.5 \mathrm{bc}$ & $0.0 \mathrm{c}$ & $1.0 \mathrm{bc}$ & $0.0 \mathrm{c}$ & $0.5 \mathrm{bc}$ \\
\hline & & Browny F1 & $0.0 \mathrm{c}$ & $0.2 \mathrm{bc}$ & $0.0 \mathrm{c}$ & $0.2 \mathrm{bc}$ & $0.0 \mathrm{c}$ & $0.5 \mathrm{bc}$ \\
\hline \multirow{6}{*}{$30^{\circ} \mathrm{C}$} & & Tueza F1 & $158.6 \mathrm{a}$ & $138.6 \mathrm{a}$ & $153.2 \mathrm{a}$ & $157.0 \mathrm{a}$ & $138.2 \mathrm{a}$ & $126.0 \mathrm{a}$ \\
\hline & Gall & Seval F1 & 3.0 bcde & $3.6 \mathrm{bcd}$ & $1.4 \mathrm{defg}$ & $1.2 \mathrm{efgh}$ & $4.6 \mathrm{bc}$ & $4.0 \mathrm{bc}$ \\
\hline & & Browny F1 & $1.0 \mathrm{fgh}$ & $0.4 \mathrm{gh}$ & $0.6 \mathrm{gh}$ & $0.2 \mathrm{~h}$ & $5.2 \mathrm{~b}$ & $2.0 \mathrm{cdef}$ \\
\hline & & Tueza F1 & $89.2 \mathrm{a}$ & $77.4 \mathrm{a}$ & $74.4 \mathrm{a}$ & $78.4 \mathrm{a}$ & $78.6 \mathrm{a}$ & $58.2 \mathrm{a}$ \\
\hline & Egg Mass & Seval F1 & $0.6 \mathrm{de}$ & $0.2 \mathrm{e}$ & $0.2 \mathrm{e}$ & $0.2 \mathrm{e}$ & $1.6 \mathrm{~cd}$ & $2.8 \mathrm{c}$ \\
\hline & & Browny F1 & $0.0 \mathrm{e}$ & $0.0 \mathrm{e}$ & $0.0 \mathrm{e}$ & $0.0 \mathrm{e}$ & $4.8 \mathrm{~b}$ & $0.6 \mathrm{de}$ \\
\hline \multirow{9}{*}{$32^{\circ} \mathrm{C}$} & & Tueza F1 & $108.2 \mathrm{a}$ & $129.8 \mathrm{a}$ & $131.2 \mathrm{a}$ & $132.8 \mathrm{a}$ & $94 a b$ & $101.2 \mathrm{a}$ \\
\hline & Gall & Seval F1 & $0.8 \mathrm{hl}$ & $1.0 \mathrm{hl}$ & $4.0 \mathrm{~g}$ & $17.4 \mathrm{f}$ & 56.2 bc & $37.6 \mathrm{~cd}$ \\
\hline & & Browny F1 & $1.4 \mathrm{hı}$ & $0.8 \mathrm{I}$ & $2.0 \mathrm{~h}$ & 18.0 ef & $39.4 \mathrm{dc}$ & $26.6 \mathrm{de}$ \\
\hline & & Tueza F1 & $71.2 \mathrm{a}$ & $109.4 \mathrm{a}$ & $73.6 \mathrm{ab}$ & $88.4 \mathrm{a}$ & $35.8 \mathrm{~d}$ & $63.4 \mathrm{abc}$ \\
\hline & Egg Mass & Seval F1 & $0.4 \mathrm{~h}$ & $0.4 \mathrm{~h}$ & $2.4 \mathrm{~g}$ & $16.2 \mathrm{f}$ & $33.2 \mathrm{de}$ & $41.4 \mathrm{bcd}$ \\
\hline & & Browny F1 & $0.2 \mathrm{~h}$ & $0.2 \mathrm{~h}$ & $1.2 \mathrm{~h}$ & 19.8 ef & $39.6 \mathrm{~cd}$ & 22.2 def \\
\hline & & Tueza F1 & $12.75 \mathrm{abc}$ & $27.49 \mathrm{a}$ & $15.51 \mathrm{ab}$ & $9.27 \mathrm{bcd}$ & $5.64 \mathrm{cde}$ & $7.59 \mathrm{bcd}$ \\
\hline & $\mathrm{Rf}$ & Seval F1 & $0.07 \mathrm{ij}$ & 0.39 hij & 0.33 hij & $2.78 \mathrm{efg}$ & 3.86 def & $4.72 \mathrm{def}$ \\
\hline & & Browny F1 & $0.004 \mathrm{j}$ & $0.01 \mathrm{ij}$ & $0.07 \mathrm{ij}$ & 0.86 ghij & $1.52 \mathrm{fgh}$ & $1.05 \mathrm{ghi}$ \\
\hline
\end{tabular}

* Tueza $\mathrm{F}_{1}$ : without Mi gene (mimi), Seval $\mathrm{F}_{1}$ : heterozygous (Mimi), Browny $\mathrm{F}_{1}$ : homozygous carrying the Mi gene (MiMi).

** The experiment was continuously conducted at $25^{\circ} \mathrm{C}$. Only one data was given in a column (168 hours).

*** Means with in the temperature sharing the same letter are not significantly different from each other at $P=0.05$ according to the LSD.

Untransformed data shown, statistical analysis was performed on $\log (x+1)$ transformed data. 
It has been shown that some accessions of $S$. peruvianum are resistant to some RKNs at high soil temperature (Ammati et al., 1986). However, these genes are not commercially available for tomato cultivation. Therefore, Mi-1 gene is the only commercially available resistance gene against some RKN and is widely used to RKN management in tomato-growing areas (Devran et al., 2010; Seid et al., 2015). However, this gene breaks down at high soil temperatures. Therefore, the effective utilization of the gene is restricted in tomato-growing areas.

Validation of M. incognita isolate and presence/absence of $M i-1$ gene on tomato cultivars is required before experiments. In the present study, this validation was performed using specific primers and our findings were in accordance with earlier studies (Randig et al., 2002; Devran \& Söğüt, 2009, 2014; Devran et al., 2013).

Several studies have been conducted on the breakdown of Mi-1 gene at high soil temperatures; however, results indicate a discrepancy in information about the duration of resistance breakdown at high soil temperatures. In this study, two experiments were conducted to clarify this phenomenon. In the first experiment, when plants were exposed to soil temperatures for different time periods and inoculated with M. incognita $\mathrm{J} 2$ at $25^{\circ} \mathrm{C}$, the resistance provided by $\mathrm{Mi}-1$ gene did not break down. Therefore, the resistance did not break down in plants exposed to high soil temperatures before nematode inoculation. Conversely, in other previous study, seedlings were exposed to high soil temperatures before nematode inoculation and then infected with $M$. incognita. Results indicated that the seedlings became increasingly susceptible to $M$. incognita above $30^{\circ} \mathrm{C}$ and were completely susceptible at $34^{\circ} \mathrm{C}$ (Zacheo et al., 1995). The difference may be due to $M$. incognita inoculum level. Araujo et al. (1982b) reported that temperature and inoculum level produced quantitative differences in resistance for both species of Meloidogyne with $28 \mathrm{~d}$ of incubation. In another study, Carvalho et al. (2015) reported that for plants exposed to $35^{\circ} \mathrm{C}$ for $3 \mathrm{~h}$ daily (midday), resistance level could be recovered by maintaining them in a low temperature for $6 \mathrm{~d}$. However, other studies reported that resistance could not be recovered (Araujo et al., 1982a; Abdul-Baki et al., 1996). This study revealed that resistance did not break down in plants exposed to high soil temperatures before nematode inoculation. This study showed that the resistance broke down in plants held at $32^{\circ} \mathrm{C}$ soil temperature for $\geq 48 \mathrm{~h}$, which is consistent with Dropkin (1969b). Although susceptible and resistant seedlings were inoculated with 20,100 and $200 \mathrm{M}$. incognita $\mathrm{J} 2$ at $32.5^{\circ} \mathrm{C}$ soil temperature, there were fewer egg masses on resistant plant roots than on susceptible plant roots. However, when plants were inoculated with 1000 and $2000 \mathrm{M}$. incognita J2, both plants showed comparable number of egg masses (Araujo et al., 1982b). Our results showed that egg masses in resistant tomato seedlings (MiMi) inoculated with $1000 \mathrm{M}$. incognita J2 were fewer than in susceptible plants (mimi). In another study, Abdul-Baki et al. (1996) reported that the resistance level in in vitro root explants was fully maintained at $31^{\circ} \mathrm{C}$, partially maintained at $34^{\circ} \mathrm{C}$ and lost at $37^{\circ} \mathrm{C}$.

Some studies have also been conducted on the effect of temperatures on plants carrying Mi-1 gene under greenhouse conditions. Cortada et al. (2008) reported that resistance conferred by Mi-1 gene reduced greatly in soil temperature above $28^{\circ} \mathrm{C}$ under greenhouse conditions in summer. The results showed differences on performance of plants carrying Mi-1 gene under greenhouse conditions.

In conclusion, the resistance provided by Mi-1 gene in tomato breaks down at soil temperatures above $28^{\circ} \mathrm{C}$ in tomato-growing areas in many parts of the world. Therefore, planting time is important for tomato plants carrying Mi-1 gene. These results showed that resistance did not break down in plants exposed to high soil temperatures before nematode inoculation. Therefore, the Mi-1 gene-mediated resistance in tomato does not break down in seedling facilities, which are not usually infested with RKN, if the soil temperature in nursery is above $28^{\circ} \mathrm{C}$. In addition, results showed resistance break down in nematode-inoculated plants held at $32^{\circ} \mathrm{C}$ for $\geq 48 \mathrm{~h}$. The findings could help in the effective use of Mi-1 gene and indicate the appropriate planting times of tomatoes bearing $\mathrm{Mi}-1$ gene for cultivation in fields prone to high soil temperatures $\left(\geq 32^{\circ} \mathrm{C}\right)$.

\section{Acknowledgments}

The authors would like to thank Multi Tohum Tar. San Tic. A.Ş. (Antalya, Turkey) for providing tomato seedlings; M.Y. Genetik Tarım Teknoloji Laboratuvar (Antalya, Turkey) for conducting heat treatments bioassays; İbrahim Mıstanoğlu (Akdeniz University) for his assistance at laboratory; and Prof. Mahmut Tör (Worcester University, UK) for the critical review. 


\section{References}

Abdul-Baki, A. A., S. A. Haroon \& D. J. Chitwood, 1996. Temperature effects on resistance to Meloidogyne spp. in excised tomato roots. Horticultural Science, 31: 147-149.

Al-Hazmi, A. S. \& S. N. Al-Nadary, 2015. Interaction between Meloidogyne incognita \& Rhizoctonia solani on green beans. Saudi Journal of Biological Sciences, 22: 570-574.

Ammati, M., I. J. Thomason \& H. E. McKiney, 1986. Retention of resistance to Meloidogyne incognita in Lycopersicon genotypes at high soil temperature. Journal of Nematology, 18: 491-495.

Arab, L. \& S. Steck, 2000. Lycopene and cardiovascular disease. The American Journal of Clinical Nutrition, 71: 16911695.

Araujo, M. T., M. J. Bassett, J. J. Augustine \& D. W. Dickson, 1982a. Effects of the temperature and duration of the initial incubation period on resistance to Meloidogyne incognita in tomato. Journal of Nematology, 14: 411-413.

Araujo, M. T., D. W. Dickson, J. J. Augustine \& M. J. Bassett, 1982b. Optimum initial inoculum levels for evaluation of resistance in tomato to Meloidogyne spp. at two different soil temperatures. Journal of Nematology, 14: 536-540.

Carvalho, M. D., L. Bendand, M. M. Vaughan, A. R. Cabrera, K. Hung, T. Cox, Z. Abdo, L. H. Allen \& P. E. A. Teal, 2015. Mi-1 mediated nematode resistance in tomatoes is broken by short-term heat stress but recovers over time. Journal of Nematology, 47: 133-140.

Clinton, S. K., C. Emenhiser, S. J. Schwartz, D. G. Bostwick, A. W. Williams, B. J. Moore \& J. W. Erdman, 1996. Cistrans lycopene isomers, carotenoids, and retinol in the human prostate. Cancer Epidemiology and Prevention Biomarkers, 5: 823-833.

Cortada, L., F. J. Sorribas, C. Ornat, I. Kaloshian \& S. Verdejo-Lucas, 2008. Variability in infection and reproduction of Meloidogyne javanica on tomato rootstocks with the Mi resistance gene. Plant Pathology, 57: 1125-1135.

Devran, Z., B. Başköylü, A. Taner \& F. Doğan, 2013. Comparison of PCR-based molecular markers for identification of Mi gene. Acta Agriculturae Scandinavica, Section B - Soil and Plant Science, 45: 395-402.

Devran, Z. \& M. A. Söğüt, 2009. Distribution and identification of root-knot nematodes from Turkey. Journal of Nematology, 41: 128-133.

Devran, Z. \& M. A. Söğüt, 2010. Occurrence of virulent root-knot nematode populations on tomatoes bearing the Mi gene in protected vegetable-growing areas of Turkey. Phytoparasitica, 38: 245-251.

Devran, Z., M. A. Söğüt \& N. Mutlu, 2010. Response of tomato rootstocks with the Mi resistance gene to Meloidogyne incognita race 2 at different soil temperatures. Phytopathologia Mediterranea, 49: 11-17.

Devran, Z. \& M. A. Söğüt, 2011. Characterizing races of Meloidogyne incognita, M. javanica and M. arenaria in the West Mediterranean region of Turkey. Crop Protection, 30: 451-455.

Devran, Z. \& M. A. Söğüt, 2014. Response of heat-stable tomato genotypes to Mi-1 virulent root-knot nematode populations. Turkish Journal of Entomology, 38: 229-238.

Devran, Z., M. A. Söğüt, U. Gözel, M. Tör \& I. H. Elekcioglu, 2008. Analysis of genetic variation between populations of Meloidogyne spp. from Turkey. Russian Journal of Nematology, 16: 143-149.

Dropkin, V. H., 1969a. Cellular responses of plants to nematode infections. Annual Review of Phytopathology, 7: $101-122$.

Dropkin, V. H., 1969b. The necrotic reaction of tomatoes and other hosts resistant to Meloidogyne: Reversal by temperature. Phytopathology, 59: 1632-1637.

Duncan, L. W. \& J. W. Noling, 1998. "Agricultural Sustainability and Nematode Integrated Pest Management, 251-287". In: Plant Nematode Interactions (Eds. K. R. Barker, G. A. Pederson \& G. L. Windham), Madison: American Society of Agronomy, $771 \mathrm{pp}$.

FAO, 2014. Production quantities of tomatoes in world. (Web page: http://www.fao.org/faostat/en/\#data/QC/visualize) (Date accessed: 20 April 2017).

Ferris, H., 1985. Density-dependent nematode seasonal multiplication rates and overwinter survivorship: A critical point model. Journal of Nematology, 17: 93-100.

Haroon, S. A., A. A. Baki \& R. N. Huettel, 1993. An in vitro test for temperature sensitivity and resistance to Meloidogyne incognita in tomato. Journal of Nematology 25: 83-88. 
Hooper, D. J., 1986. “Extraction of Free-Living Stages from Soil, 5-30”. In: Laboratory Methods for Work with Plant and Soil Nematodes (Ed. J. F. Southey). Her Majesty's Stationery Office, London, 202 pp.

Hussey, R. S., 1985. "Host Parasite Relationship and Associated Physiological Changes, 143-153". In: An Advanced Treatise on Meloidogyne Vol. I. Biology and Control (Eds. J. N. Sasser \& C. C. Carter). Raleigh, North Carolina State University Graphics, 422 pp.

Lobna, H., R. Hajer, M. B. Naima \& H. R. Najet, 2016. Studies on disease complex incidence of Meloidogyne javanica and Fusarium oxysporum f.sp. lycopersici on resistant and susceptible tomato cultivars. Journal of Agricultural Science and Food Technology, 2: 41-48.

Manzanilla-López, R. H. \& J. L. Starr, 2009. “Interactions with Other Pathogens, 223-245”. In: Root-knot Nematodes (Eds. R. N. Pery, M. Moens \& J. L. Starr). Wallingford, CAB International, 531 pp.

Mıstanoğlu, I., T. Özalp \& Z. Devran, 2016. Response of tomato seedlings with different number of true leaves to Meloidogyne incognita Kofoid and White, 1919 Chitwood, 1949. Turkish Journal of Entomology, 40: 377-383.

Moens, M., R. N. Perry \& J. L. Starr, 2009. "Meloidogyne Species a Diverse Group of Novel and Important Plant Parasites, 1-17”. In: Root- Knot Nematodes (Eds. R. N. Perry, M. Moens \& J. L. Starr). CABI, London, 488 pp.

Nombela, G., V. M. Williamson \& M. Muniz, 2003. The root-knot nematode resistance gene Mi.1.2 of tomato irresponsible for resistance against the whitefly Bemisia tabaci. Molecular Plant-Microbe Interactions, 16: 645-649.

Randig, O., M. Bongiovanni, R. M. Carneiro \& P. Castagnone-Sereno, 2002. Genetic diversity of root-knot nematodes from Brazil and development of SCAR marker specific for the coffee damaging species. Genome, 45: 862-870.

Roberts, P. A. \& I. J. Thomason, 1986. Variability in reproduction of isolates of Meloidogyne incognita and M. javanica on resistant tomato genotypes. Plant Disease, 70. 547-51.

Rossi, M., F. L. Goggin, S. B. Milligan, I. Kaloshian, D. E. Ullman \& V. M. Williamson, 1998. The nematode resistance gene $\mathrm{Mi}$ of tomato confers resistance against the potato aphid. Proceedings of the National Academy of Sciences, 95: 9750-9754.

Seah, S., V. M. Williamson, B. E. Garcia, L. Mejia, M. S. Salus, C. T. Martin \& D. P. Maxwell, 2007. Evaluation of a codominant SCAR marker for detection of the Mi-1 locus for resistance to root-knot nematode in tomato germplasm. Tomato Genetics Cooperative Report, 57: 37-40.

Seid, A., C. Fininsa, T. Mekete, W. Decraemer \& W. M. Wesemael, 2015. Tomato Solanum lycopersicum and rootknot nematodes Meloidogyne spp. -a century-old battle. Nematology, 17 (9): 995-1009.

Siddiqi, M. R., 2000. Tylenchida, Parasites of Plants and Insects. 2nd Edition. Wallingford, CABI Publishing, CABI International, $805 \mathrm{pp}$.

Siddiqui, Z. A., M. Shehzad \& S. Alam, 2014. Interactions of Ralstonia solanacearum and Pectobacterium carotovorum with Meloidogyne incognita on potato. Archives of Phytopathology and Plant Protection, 47: 449-455.

Smith, P. G., 1944. Embryo culture of a tomato species hybrid. Proceedings of the American Society for Horticultural Science, 44: 413-416.

Starr, J. L., M. J. Jeger, R. D. Martyn \& K. Schilling, 1989. Effects of Meloidogyne incognita and Fusarium oxysporum f. sp. vasinfectum on plant mortality and yield of cotton. Phytopathology, 79: 640-646.

Taylor, A. L. \& J. N. Sasser, 1978. Biology, Identification and Control of Root-Knot Nematodes. Raleigh, North Carolina State University Graphics, $111 \mathrm{pp}$.

Zacheo, G., T. Bleve-Zacheo, D. Pacoda, C. Orlando \& R. D. Durbin, 1995. The association between heat-induced susceptibility of tomato to Meloidogyne incognita and peroxidase activity. Physiological and Molecular Plant Pathology, 46: 491-507. 